\title{
Multivisceral Resections for Locally Advanced Colorectal Cancer: Morbidity and Mortality
}

\author{
Ali Sürmelioğlu' ${ }^{1}$, Metin Tilki², Gülten Çiçek Okuyan² \\ ${ }^{1}$ Department of Gastrointestinal Surgery, University of Health Sciences Turkey, Hamidiye Faculty of Medicine, Haydarpaşa Numune \\ Health Application and Research Center, Istanbul, Turkey \\ ${ }^{2}$ Department of General Surgery, University of Health Sciences Turkey, Hamidiye Faculty of Medicine, Haydarpaşa Numune Health \\ Application and Research Center, Istanbul, Turkey
}

\begin{abstract}
Introduction: Multivisceral organ resection is recommended in patients with locally advanced colorectal cancer. The aim of this study was to determine the influence of additional organ resection on morbidity and mortality on short term.

Methods: Patients who underwent curative resection for colorectal cancer were included in the study. They were divided into two groups as multivisceral resection groups (MRGs) and standard resection groups (SRGs). The patients were compared in terms of demographics, tumor localization, operation time, blood loss, length of hospital stay, and post-operative morbidity and mortality. In statistical analysis, Mann-Whitney $U$ and chi-square tests were used.

Results: Thirty-two (10.1\%) of 316 patients were in the MRG and 284 (89.9\%) in the SRG. Male/female ratio, presence of comorbid diseases, and tumor localization were similar in the groups. Hospital stay (8.4 \pm 4.2 vs. 8.2 \pm 6.2 days) was also similar. Operation time (221 \pm 62.3 vs. $181 \pm 70.1 \mathrm{~min}$ ) was longer and blood loss (180 [50-410] cc vs. 150 [40-390] cc) was significantly higher in the MRG $(p<0.001$ and $p<0.001$, respectively). There was no statistically significant difference with regard to morbidity (21.8\% vs. $20.8 \%$ ) and mortality (3.1\% vs. 3.5\%). In the MRG, histopathologically confirmed tumoral invasion (T4) was detected in 17 (53.1\%) patients for whom multiorgan resection was performed.

Discussion and Conclusion: Multiorgan resections can be performed with acceptable morbidity and mortality in specialized centers.

Keywords: Colorectal carcinoma; morbidity; mortality; multivisceral resection.
\end{abstract}

C olorectal cancer is at the second rank among the cancers which are most frequently observed in the United States ${ }^{[1,2]}$. In $5-10 \%$ of all cases with colorectal cancer, the adjacent organs are involved by the disease ${ }^{[3,4]}$. Until 50 years ago, adjacent organ involvement was accepted as an irresectability criterion ${ }^{[5,6]}$. It is not possible to determine preoperatively or intraoperatively whether adjacent organ infiltration is a true malignant invasion or peritumoral inflammatory reaction without histopathological evaluation $^{[7]}$.

In patients with colorectal carcinoma, residual tumor is an important criterion for survival. In cases where tumor is left

Correspondence (illetişim): Ali Sürmelioğlu, M.D. Saglik Bilimleri Universitesi Hamidiye Tip Fakultesi, Haydarpasa Numune Saglik Uygulama ve Arastirma Merkezi, Gastroenteroloji Cerrahisi, Istanbul, Turkey

Phone (Telefon): +90 5055625546 E-mail (E-posta): surmeliali@yahoo.com

Submitted Date (Başvuru Tarihi): 18.02.2021 Accepted Date (Kabul Tarihi): 26.02 .2021

Copyright 2021 Haydarpaşa Numune Medical Journal

OPEN ACCESS This is an open access article under the CC BY-NC license (http://creativecommons.org/licenses/by-nc/4.0/).

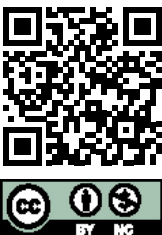


behind, the average survival period reported to be 11.6 months. If the tumor is placed in the rectum and there is also poor grade or apical lymph involvement, 1 year survival ratio is $7 \%{ }^{[2]}$. Together with these results, if adjacent organ invasion is determined during surgery, wide resection should not be avoided. At this point, multivisceral resection is performed in more than $10 \%$ of patients with locally advanced colorectal cancer and it is accepted as the only chance for cure ${ }^{[2,8-10]}$. In this study, we aim to examine the influence of additional organ resection on morbidity and mortality on short term.

\section{Materials and Methods}

Between January 2014 and November 2020, 316 patients who underwent curative resection for colorectal cancer were retrospectively retrieved from a prospectively maintained database. Then, the patients were divided into two groups as multivisceral resection group (MRG) and standard resection group (SRG). Patients who were operated on for intestinal obstruction, perforation, or serious bleeding were not included in the study. Patients with distant metastasis were also excluded from the study. While standard lymph node dissection with colon or rectum resection was performed in the patients in the SRG, at least one organ was resected additionally in patients in the MRG. The patients in both groups were compared in terms of age, gender, length of hospital stay, medical history, tumor localization, operation time, blood loss, and post-operative morbidity and mortality. Since our study was conducted retrospectively by evaluating patient results, the Ethics Committee approval was not obtained. Comparisons were made with Mann-Whitney $U$ and Chi-square tests. P-values under 0.05 were evaluated as statistically significant.

\section{Results}

A total of 316 patients were enrolled to the study. Thirtytwo $(10.1 \%)$ of these patients were in the MRG and 284 $(89.9 \%)$ in the SRG. In the MRG and SRG, there was no statistically significant difference in terms of age $(63.9 \pm 14.0$ vs. $65.2 \pm 11.9$ years), gender (male: $53.2 \%$ vs. $54.2 \%$ ), and presence of comorbid diseases [13 (40.6\%) vs. 127 (44.7\%)] ( $p>0.05$ ). Tumor localizations were also similar between the groups, but in both groups, the majority of the patients were operated on for rectal cancer (Table 1).

While the operation time was $221 \pm 62.3 \mathrm{~min}$ in the MRG, it was $181 \pm 70.1 \mathrm{~min}$ in the SRG. Blood loss was $180 \mathrm{cc}$ (50-410) cc in the MRG but $150 \mathrm{cc}(40-390)$ in the SRG. The differences were statistically significant between two groups for both parameters $(p<0.001$ and $p<0.001$, respectively). Length of hospital stay was not different between the groups $(8.4 \pm 4.2$ days in the MRG vs. $8.2 \pm 6.2$ days in the SRG; $p>0.05$ ). While in the MRG, the post-operative total morbidity was 7 (21.8\%), it was $59(20.8 \%)$ in the SRG. In terms of mortality, no significant difference was determined between the groups (Table 2).

The organs which were removed additionally in the MRG are shown in Table 3 . The most frequently removed organ was the small intestine $[n=6(18.7 \%)]$ (Table 3 ). While single organ was removed in 26 (81.3\%) patients in the MRG, more than 1 organ was removed in 6 (18.7\%) patients (Table 4). While, in 15 (46.9\%) of 32 patients in the MRG, the tumors were T3 pathologically, it was T4 in 17 (53.1\%) patients.

\section{Discussion}

The strongest prognostic effect of complete removal of the tumor with multimodal treatment strategies in colorectal

Table 1. Demographics and clinical characteristics of patients in the MRG and SRG

\begin{tabular}{|c|c|c|c|}
\hline Patient characteristics & MRG $n=32(10.1 \%)$ & SRG n=284 (89.9\%) & $\mathbf{p}$ \\
\hline Age (year)* & $63.9 \pm 14.0$ & $65.2 \pm 11.9$ & 0.679 \\
\hline Gender (female/male) & $15(46.8) / 17(53.2)$ & $130(45.8) / 154(54.2)$ & 0.391 \\
\hline Comorbid disease & $13(40.6)$ & $127(44.7)$ & 0.125 \\
\hline \multicolumn{4}{|l|}{ ASA scores } \\
\hline ASA $1+$ ASA 2 & $19(59.4)$ & $185(65.1)$ & 0.347 \\
\hline ASA 3 + ASA 4 & $13(40.6)$ & $99(34.9)$ & \\
\hline \multicolumn{4}{|l|}{ Tumor localization } \\
\hline Right colon & $6(18.7)$ & 65 (22.9) & 0.804 \\
\hline Left colon & $10(31.3)$ & $94(33.1)$ & \\
\hline Rectum & $16(50.0)$ & $141(44.0)$ & \\
\hline
\end{tabular}

*Values presented as mean \pm SD and percent (\%), ASA score: American Society of Anesthesiologists score, MRG: Multivisceral resection group, SRG: Standard resection group. 
Table 2. Characteristics of operation and post-operative period in the MRG and SRG

\begin{tabular}{lccc}
\hline & MRG $\mathbf{n = 3 2 ( 1 0 . 1 \% )}$ & SRG n=284 (89.9\%) & p \\
\hline Operation time (min) & $221 \pm 62.3$ & $181 \pm 70.1$ & $<0.001$ \\
Blood loss (ml) & $180(50-410)$ & $150(40-390)$ & $<0.001$ \\
Length of hospital stay (day) & $8.4 \pm 4.2$ & & \\
Morbidities* & & & \\
$\quad$ Surgical site infection & $5(15.6)$ & $37(13.0)$ & $16(5.6)$ \\
Intra-abdominal collection/abscess & $2(6.2)$ & $8(2.8)$ & 0.217 \\
Evisceration & $1(3.1)$ & $13(4.6)$ & 0.141 \\
Anastomotic leakage & $2(6.2)$ & $15(5.3)$ & $9(3.2)$ \\
Ileus & $2(6.2)$ & 0.214 \\
Bleeding & $1(3.1)$ & $24(8.4)$ \\
Non-surgical morbidity & $3(9.4)$ & $59(20.8)$ \\
Total & $7(21.8)$ & $10(3.5)$ \\
Mortality & $1(3.1)$ & 0.123 \\
\hline
\end{tabular}

*Some patients have developed more than 1 morbidity. Values presented as mean \pm SD and percent (\%), MRG: Multivisceral resection group, SRG: Standard resection group.

Table 3. Single additional organ resection in the MRG

\begin{tabular}{lc}
\hline Organ & $\mathbf{2 6}(\mathbf{8 1 . 3 \% )}$ \\
\hline Small intestine & $6(18.7)$ \\
Bladder wall resection & $4(12.5)$ \\
Vagina wall resection & $3(9.4)$ \\
Uterus & $2(6.2)$ \\
Gastric wedge resection & $2(6.2)$ \\
Prostate & $2(6.2)$ \\
Spleen & $1(3.1)$ \\
Abdominal wall & $1(3.1)$ \\
Ureter & $1(3.1)$ \\
Ovary & $1(3.1)$ \\
Pancreas & $1(3.1)$ \\
Duodenum wedge resection & $1(3.1)$ \\
Liver wedge resection & $1(3.1)$ \\
\hline
\end{tabular}

Values presented as percent (\%); MRG: Multivisceral resection group.

carcinoma has been shown in studies ${ }^{[7,11,12]}$. Moynihan, first in 1926 by defining locally advanced CRC, argued unblock extended resection for involved organs and structures ${ }^{[13]}$. The event that reinforces this idea was the publication of first series of 42 patients with multivisceral resection in 1946. Sugarbaker stated in his publication that colon with tumor should be removed with involved tissue or organ ${ }^{[14]}$. It is very difficult to distinguish the infiltration of locally advanced cancers to the surrounding tissues from inflammatory reaction without histopathology and frozen is not helpful in determining the actual infiltration.

It has been shown that when the involved organ has not
Table 4. More than 1 additional organ resection

\begin{tabular}{lc}
\hline Organ & $\mathbf{6 ( 1 8 . 7 \% )}$ \\
\hline Small intestine/bladder & $1(3.1)$ \\
Pancreas/spleen & $1(3.1)$ \\
Vagen/uterus & $1(3.1)$ \\
Prostate/seminal vesicle & $1(3.1)$ \\
Stomach/pancreas/spleen & $1(3.1)$ \\
Small intestine/bladder/uterus & $1(3.1)$ \\
\hline
\end{tabular}

been resected, local recurrence increases, and the mean survival decreases, if it is suspicious with infiltration. Infiltration of the tumor to adjacent organs is sometimes observed during surgery. Histopathological examination shows whether it is tumor infiltration or not. Therefore, intestine with tumor should be removed together with adjacent organs and it should not be resected solely. As the primary aim of the surgeons is to avoid recurrence and provide long-term survival, $\mathrm{RO}$ resection should be the target ${ }^{[7,9,10,15,16]}$. In our study, R0 resection was achieved in $90 \%$ of the patients in the MRG. This rate is similar with the other studies ${ }^{[4,7,17]}$. It is reported that the mean survival of patients with multivisceral resection to maintain $\mathrm{RO}$ resection is between 40 and $70 \%[4,7,18]$. However, it is reported in many studies that the survival rates decrease when residual tumor is left behind ${ }^{[3,7,15,19]}$.

Derici et al. ${ }^{[20]}$ compared morbidity after standard resection to multivisceral resection and reported that morbidity was as high as $60 \%$ in multivisceral resection, but $21 \%$ for standard resection. Yet in other studies conducted in pa- 
tients who underwent multivisceral resection, morbidity was reported to be high. However, in this study, mortality was low ${ }^{[4,10,15]}$.

In the literature, reported morbidity rates for multivisceral resections are between $11.4 \%$ and $49.1 \%$ and the mortality rates are between $0 \%$ and $7.5 \%[4,8,19,21]$. In our study, while the morbidity was $21.8 \%$ and $20.8 \%$ in the MRG and SRG, respectively, the mortality was $3.1 \%$ versus $3.5 \%$. Although these ratios are consistent with the literature, the low ratios in our study could be attributed to the fact that all operations were performed by or under supervision of a senior surgeon. Moreover, there was not a significant statistically difference between the two groups in terms of morbidity and mortality. This also shows that multivisceral resections can be performed safely. While in some studies performed, higher morbidity and mortality are observed in the MRG when compared to the SRG, no difference was observed among the two groups in numerous other studies ${ }^{[3-5,9,10,15]}$. In some studies, multivisceral resection rates were reported between 7 and $16 \%[8,9]$. We have found that rate as $10.1 \%$. In our study, these results are consistent with the literature. In studies conducted in patients who underwent unblock resection, histopathologically proven actual rate of invasion (T4) was between 33 and $84 \%{ }^{[8-10]}$. In our study, this ratio was $53.1 \%$. In our series, additional organs were removed after evaluation of the tumor and the surrounding organs, and the resection was performed with the suspicion of tumoral invasion. This shows that it is not possible to determine the existence of invasion in adjacent organ involvement without histopathology. Nevertheless, we believe that unblock resection during surgery would be beneficial.

In the literature, the most frequently resected organs are reported as small bowel, bladder, and vagina wall $[7,15,16]$. In our study, small intestine (18.7\%), bladder (12.5\%), and vagina wall resection (9.4\%) were the most frequently removed adjacent organs. In $81.3 \%$ of the patients, only one additional organ resection was performed, and in $18.7 \%$ of them, more than 1 organ resection was performed.

\section{Conclusion}

In patients with locally advanced colorectal carcinoma, R0 resection including the involved adjacent organs should be performed. These multiorgan resections can be performed with acceptable morbidity and mortality in specialized centers.

Ethics Committee Approval: Retrospective study.

Peer-review: Externally peer-reviewed.
Authorship Contributions: Concept: A.S., M.T.; Design: A.S., G.Ç.O.; Data Collection or Processing: M.T., G.Ç.O.; Analysis or Interpretation: A.S., M.T., G.Ç.O.; Literature Search: A.S., M.T.; Writing: A.S.

Conflict of Interest: None declared.

Financial Disclosure: The authors declared that this study received no financial support.

\section{References}

1. Mayo SC, Pulitano C, Marques H, Lamelas J, Wolfgang CL, de Saussure W, et al. Surgical management of patients with synchronous colorectal liver metastasis: A multicenter international analysis. J Am Coll Surg 2013;216:707-16. [CrossRef]

2. Hohenberger W, Reingruber $B$, Merkel S. Surgery for colon cancer. Scand J Surg 2003;92:45-52. [CrossRef]

3. Yun SH, Yun HR, Lee WS, Cho YB, Lee WY, Chun HK. The clinical outcome and prognostic factors after multi-visceral resection for advanced colon cancer. EJSO 2009;35:721-7. [CrossRef]

4. Gebhardt C, Meyer W, Ruckriegel S, Meier U. Multivisceral resection of advanced colorectal carcinoma. Langenbecks Arch Surg 1999;384:194-9. [CrossRef]

5. Staib L, Link KH, Blatz A, Beger HG. Surgery of colorectal cancer: surgical morbidity and five-and ten-year results in 2400 patients monoinstitutional experience. World J Surg 2002;26:59-66. [CrossRef]

6. Lehnert T, Methner M, Pollok A, Schaible A, Hinz U, Herfarth C. Multivisceral resection for locally advanced primary colon and rectal cancer: An analysis of prognostic factors in 201 patients. Ann Surg 2002;235:217-25. [CrossRef]

7. Croner RS, Merkel S, Papadopoulos T, Schellerer V, Hohenberger W, Goehl J. Multi-visceral resection for colon carcinoma. Dis Colon Rectum 2009;52:1381-6. [CrossRef]

8. Nakafusa Y, Tanaka T, Tanaka M, Kitajima Y, Sato S, Miyazaki K. Comparison of multivisceral resection and standard operation for locally advanced colorectal cancer: Analysis of prognostic factors for short-term and long-term outcome. Dis Colon Rectum 2004;47:2055-63. [CrossRef]

9. Izbicki JR, Hosch SB, Knoefel WT, Passlick B, Bloechle C, Broelsch CE. Extended resections are beneficial for patients with locally advanced colorectal cancer. Dis Colon Rectum 1995;38:1251-6. [CrossRef]

10. Gall FP, Tonak J, Altendorf A. Multivisceral resections in colorectal cancer. Dis Colon Rectum 1987;30:337-41. [CrossRef]

11. Hermanek P, Wittekind C. Residual tumor (R) classification and prognosis. Semin Surg Oncol 1994;10:12-20. [CrossRef]

12. Hermanek P, Gall FP, Altendorf A. Prognostic groups in colorectal carcinoma. J Cancer Res Clin Oncol 1980;98:185-93.

13. Moynihan B. Abdominal Operations. Philadelphia, PA: WB Saunders; 1916. p. 19.

14. Sugarbaker ED. Coincident removal of additional structures in resections for carcinoma of the colon and rectum. Ann Surg 1946;123:1036-46. [CrossRef]

15. Sokmen S, Terzi C, Unek T, Alanyali H, Fuzun M. Multivisceral 
resections for primary advanced rectal cancer. Int J Colorectal Dis 1999;14:282-5. [CrossRef]

16. Derici H, Unalp HR, Kamer E, Bozdag AD, Tansug T, Nazli O, et al. Multivisceral resections for locally advanced rectal cancer. Colorectal Dis 2008;10:453-9. [CrossRef]

17. Kasperk R, Riesener KP, Klink A, Schumpelick V. Multiorgan surgery in rectal cancer extended therapy or improvement of prognosis? Zentralbl Chir 1999;124:1074-8.

18. Park S, Lee YS. Analysis of the prognostic effectiveness of multi-visceral resection for locally advanced colorectal cancer. J Korean Soc Coloproctol 2011;27:21-6. [CrossRef]
19. Govindarajan A, Fraser N, Cranford V, Wirtzfeld D, Gallinger S, Law CM, et al. Predictors of multivisceral resection in patients with locally advanced colorectal cancer. Ann Surg Oncol 2008;15:1923-30. [CrossRef]

20. Hermanek P. Multivisceral resection of colorectal cancer--experiences of the colorectal cancer study group. Langenbecks Arch Chir Suppl Kongressbd 1992;5-100.

21. Eisenberg SB, Kraybill WG, Lopez MJ. Long-term results of surgical resection of locally advanced colorectal carcinoma. Surgery 1990;108:779-85. 